Article

\title{
Combining GIS Applications and Method of Multi-Criteria Decision-Making (AHP) for Landfill Siting in Al-Hashimiyah Qadhaa, Babylon, Iraq
}

\author{
Ali Chabuk ${ }^{1,2}$, Nadhir Al-Ansari ${ }^{1, *}$ (D) , Hussain Musa Hussain ${ }^{3}$, Sven Knutsson ${ }^{1}$ (D), \\ Roland Pusch ${ }^{1}$ and Jan Laue ${ }^{1}$ \\ 1 Department of Civil Environmental and Natural Resources Engineering, Lulea University of Technology, \\ Lulea 971 87, Sweden; ali.chabuk@ltu.se (A.C.); Sven.Knutsson@ltu.se (S.K.); \\ drawrite.se@gmail.com (R.P.); jan.laue@ltu.se (J.L.) \\ 2 Department of Environment Engineering, College of Engineering, University of Babylon, \\ Babylon 51001, Iraq \\ 3 Department of Geology, Faculty of Science, University of Kufa, Kufa 32003, Iraq; Musa@uokufa.edu.iq \\ * Correspondence: nadhir.alansari@ltu.se; Tel.: +46-767-768-027
}

Received: 19 September 2017; Accepted: 24 October 2017; Published: 25 October 2017

\begin{abstract}
Landfill siting is a complex process. It is one of the major problems in waste management, where many factors should be taken into consideration when selecting a suitable site for landfill in any given area. At the present time, there are many random waste disposal sites distributed throughout Al-Hashimiyah Qadhaa in Iraq. In this study, the Geographic Information System (GIS) and the Analytical Hierarchy Process (AHP) were used to select the best sites for landfill. The process of selecting sites for landfill in Al-Hashimiyah Qadhaa comprised two steps. First, fifteen different criteria were mapped and incorporated into overlay analyses within GIS software to produce the final suitability index map for the site. The second step comprises the exclusion of unsuitable areas from the final map to simplify identification of the candidate sites for landfill in the study area. The weightings of criteria were identified using AHP, and the weightings of the sub-criteria of each criterion were determined based on multiple factors. In order to accommodate solid waste from 2020 until 2030, two suitable candidate landfill sites were determined which fulfill the required area of $1.013 \mathrm{~km}^{2}$ with areas of $1.374 \mathrm{~km}^{2}$ and $1.288 \mathrm{~km}^{2}$ respectively.
\end{abstract}

Keywords: AHP method; GIS software; landfill site; solid waste

\section{Introduction}

Solid waste management is considered a major issue for the municipality directorates in the cities of developing countries. The increase in the quantity of waste generated arises from the effects of many factors, such as population growth, rapid economic growth, improvements in living standards, etc. [1,2]. For solid waste management, many effective techniques of disposal of municipal solid waste have been used, such as landfills, recycling, thermal treatment and biological treatment $[3,4]$. For example, sanitary landfills have been adapted to the management of solid waste in many countries, even if other techniques of waste management are used. In countries that recycle or burn large parts of their waste, the resulting materials from these processes are still requires dumping. This process is considered relatively cheap and simple to be used [5,6].

Landfill siting is considered a complex task for planners and authorities because this process needs to take into consideration many factors. These factors are, for example, increasing population densities, growing environmental awareness, reduced land availability for landfills and increasing political and social opposition to the establishment of landfill sites, government regulation, government and municipality funding, and urbanization [7-9]. 
The Babylon Governorate, Babylon, Iraq produced an annual amount of 522,463 tonnes of solid waste in 2015 [10]. Presently, there is no landfill site within the study area that conforms with the scientific and environmental criteria for selecting such sites. There are just waste disposal sites distributed throughout the cities of Al-Hashimiyah Qadhaa. All these waste-disposal sites did not get the approval from official authorities. Regrettably, the hallmarks of the impact of waste disposal sites in the Babylon Governorate are groundwater contamination, surface water pollution, large-scale greenhouse-gas emissions, spontaneous fires, and increasing numbers of insects and rodents in and around the area [11].

To solve the problem of landfill siting, the integration of the Geographic Information System (GIS) and the Analytic Hierarchy Process (AHP) method was used. The GIS software (version 10.4) plays a significance role in contributing to overlay analysis for the selection of a landfill site because it has a high ability to manage large volumes of spatial data and consider many factors from a variety of sources [4,12-14]. Geographic information systems (GIS) has high ability to deal with the constraints of necessary social, environmental, economic, etc. [15]. The combining GIS with data of Remote Sensing was used to select the candidate sites $[16,17]$. The new application of GIS open source was created to obtain the specific sites [18].

The AHP method was developed by Saaty (1980), and it is one of the most common for the methods of Multi-Criteria Decision Making (MCDM) because it is based on theoretical foundation. It has a high ability to solve complex problems during the process of decision-making in different fields $[19,20]$. AHP is used to determine the consistency of weightings for criteria through constructing a matrix of pair-wise comparisons.

AHP and GIS have been used for a range of applications in various fields, including the assessment of groundwater pollution potential [21], soil environment [22], and health care and urban planning [23].

In the literature, many researchers have used a combination of GIS software and AHP to select suitable landfill sites among many candidate sites (e.g., [24-28]).

The main goal of this study is to select the most suitable candidate sites for landfill in Al-Hashimiyah Qadhaa, Iraq, that fulfill the environmental and scientific criteria. For achieving this goal significant criterion that can affect the environment were considered through combining the Analytic Hierarchy Process (AHP) method and GIS software.

The process of selecting a landfill site comprises many steps that need to be performed using GIS software: (1) The area of each criterion map is divided into categories to suit the requirements, and then each category is given a suitable weighting; (2) Determining the final map for landfill siting using the special analysis tool in GIS "Map Algebra-Single Output Map Algebra"; (3) Exclusion of unsuitable areas for sites for landfill with some of their buffer zones to simplify the process of selecting candidate sites for landfill $[12,14]$.

\section{Study Area}

Al-Hashimiyah Qadhaa is located in the southern part of the Babylon Governorate in Iraq (longitude $44^{\circ} 27^{\prime} 45^{\prime \prime} \mathrm{E}$ and $45^{\circ} 12^{\prime} 4^{\prime \prime} \mathrm{E}$, and latitude $32^{\circ} 31^{\prime} 24^{\prime \prime} \mathrm{N}$ and $32^{\circ} 12^{\prime} 10^{\prime \prime} \mathrm{N}$ ) (Figure 1). This Qadhaa consists administratively of three cities: Al-Hashimiyah, Al-Medhatyah and Al-Shomaly.

Al-Hashimiyah Qadhaa covers an area of $1046 \mathrm{~km}^{2}$, which represents $19.7 \%$ of the total area of the governorate [29]. The population of Al-Hashimiyah Qadhaa in 2015 was 286,409 inhabitants, which represents $13.67 \%$ of the total population of the Babylon Governorate [30]. The population density in this Qadhaa is 273.8 inhabitants $/ \mathrm{km}^{2}$.

The solid waste quantity expected in 2030 in Al-Hashimiyah Qadhaa is 100,155 tonnes based on an expected population in 2030 in this Qadhaa of 445,566 inhabitants. The cumulative quantity of solid waste expected from 2020 to 2030 is 911,695 tonnes, according to calculations made by (Chabuk et al., 2015), where the average generation rate of solid waste is $0.49 \mathrm{~kg} /$ (capita. day) (for the last five years: 2009-2013) and $0.52 \mathrm{~kg}$ /(capita. day) in 2013. These calculations were done based on a $2.99 \%$ average 
annual population growth and a $1 \%$ yearly rate of increment for waste generation in Al-Hashimiyah Qadhaa. The density of waste in waste disposal sites is $450 \mathrm{~kg} / \mathrm{m}^{3}$ in the Al-Hashimiyah Qadhaa [31].

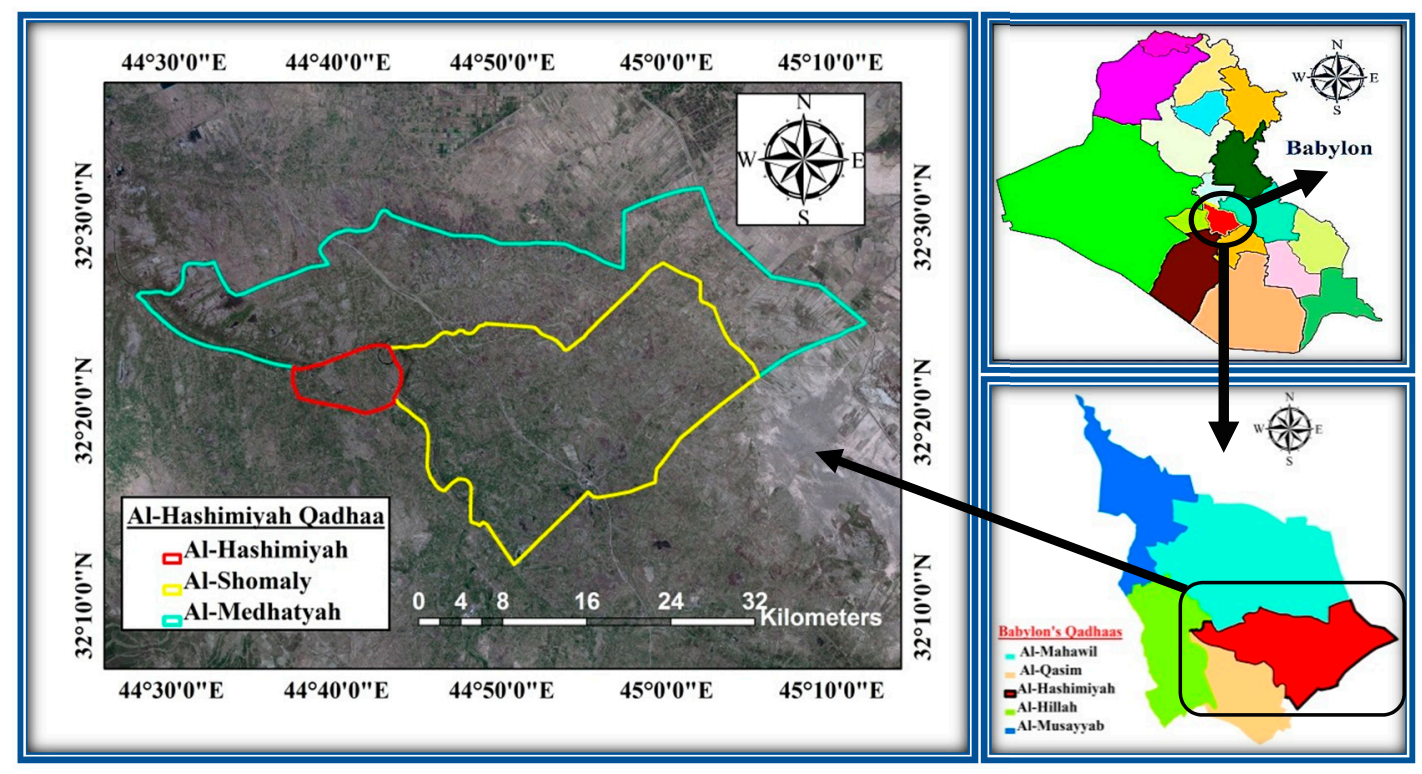

Figure 1. The study area of the Al-Hashimiyah Qadhaa.

\section{Methodology}

To evaluate the study area for the selection of a suitable site for landfill, GIS and its special analysis tools were used to prepare map layers covering the most important fifteen criteria in the study area according to expert's opinion in this field. The model of landfill siting, depending on current criteria, can be divided in the following ways:

(1). Reviewing the previous literature.

(2). Preparing the database of digital maps within GIS software for the study area.

(3). Creating suitable buffer zones or special constraints around important areas to suit each criterion map.

(4). Determination of the weightings of the sub-criteria based on the opinion of experts, literature, environmental and scientific requirements and governmental regulations.

(5). Determination of the weightings for the criteria using the AHP model.

(6). Exclusion of unsuitable areas for landfill siting from the resulting final map of this study.

(7). Determination of a suitability index to apply to candidate sites for landfill.

\subsection{The Hierarchical Structure Tree for Landfill Siting}

The initial step of the methodology for this study involves identifying a hierarchy for the decision problem. The main aim of the decision problem was selecting candidate sites in Al-Hashimiyah Qadhaa. The hierarchical structure was built based on the opinions of experts in this field, previous research and data available in the study area. It includes three levels (Figure 2). The first level represents two broad categories: natural environmental factors, and artificial factors. The second level includes six main factor groups: hydrological, land, topographical, infrastructure, accessibility and social-cultural factors. The third level comprises all fifteen criteria which were used in the current study to determine candidate sites for landfill.

The landfill siting is considered as a complex process related to solid waste management systems due to government funding, government regulations, social and environmental factors, economic factors, and increase public \& political opposition to the landfill sites establishment. 
The groundwater in Al-Hashimiyah Qadhaa varies in depth from 1.445 to 6.943 meters below the ground surface in most of the areas. This range of depths is considered shallow. Landfills should be located over the surface of the ground to prevent groundwater from pollution [32]. The "river" criterion was adopted in order to protect surface water of Shatt Al-Hilla river (which is passing through the study area) from contamination by leachate [33,34].To reduce the potential of leachate leaking from the landfill and to avoid the risk of flooding [35], the criterion of topography (elevation) was selected.

The criterion of "slope" was used, where an area with a very steep slope will increase drainage of pollutants from the landfill site to surrounding areas [8] as well as increasing the risk of leachate flowing from high slopes to flat and low areas or bodies of water.

To protect the human and environment, the important categories within the criterion of "land use" were classified and were given them the suitable score that deserved.

To protect the agricultural lands from contamination, that "agricultural lands use" criterion for Al-Hashimiyah Qadhaa was divided into three categories are agricultural land, orchards and unused land. Each category was given the appropriate value.

The soil of Babylon Governorate consists of clastic materials, which is known alluvial deposits [36]. There are 6 types of soils in Al-Hashimiyah Qadhaa [37]. To protect the landfills from the movement of leachate within soil layers and to reduce the soil consolidation, the "soil" criterion was used.

The "roads" criterion was used for many considerations. Distances from roads to a landfill site should be sufficient to ensure there are no negative aesthetic impacts [3]. Moreover, economic factors must be taken into consideration, and a landfill site should be located within a reasonable distance of existing roads in order to reduce the cost of construction of roads leading to the site in future $[8,15,38]$.

The criterion of "railway" was adopted in order to prevent both potential land subsidence and visual intrusion when selecting the landfills [39].

For the "urban centers" criterion, many researchers suggested that the appropriate distance from the borders of urban areas to a landfill site should be at a suitable distance due to the economic factors and impact on the general public. The cost of this land as well as health and safety laws often prevent siting of a landfill within the boundaries of an urban area. Important factors to consider are noise, decreases in property value [38], odor, aesthetics [40], as well as ensuring that the urban area retains the potential to expand in the future [41].

The "villages" criterion was adopted because there are many villages distributed throughout the study area. The literature recommended a minimum distance from a landfill site to villages that should be at a suitable distance $[42,43]$ to protect human and environment from insect and rodent infestation, odors, disease, and sometimes population suffocation because of burning the waste in these sites. In addition, there is an increase the social opposition to the establishment of landfill sites.

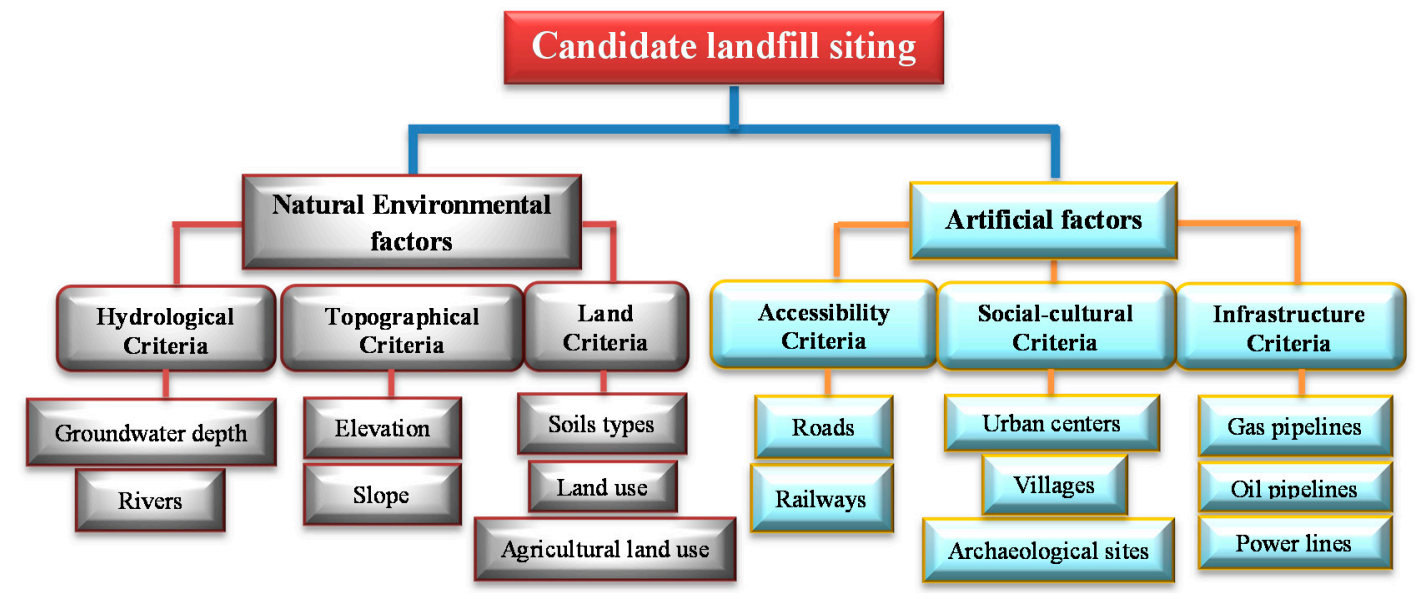

Figure 2. Tree diagrams of the decision process developed for selection of a suitable landfill site [44]. 
For the criterion of "archaeological", Babylon Governorate has a rich history and is home to a number of significant archaeological and religious sites. These areas are considered absolutely inappropriate to be within or near a landfill site because of their high historical value and importance for tourism (and the development of tourism) in this governorate.

The "power lines" criterion was selected to avoid risks associated with high-voltage whilst taking into account the need to provide electricity to the infrastructure of the landfill site [32,34].

The criteria of "gas pipelines" and "oil pipelines" were adopted in the current study to avoid the serious impact of spontaneous fires that result from burning of solid waste on the gas and oil pipelines. Consequently, protection the important infrastructure which is considered the valuable source for national wealth.

All area in Al-Hashimiyah Qadhaa is covered by alluvial deposits at depth of more than $50 \mathrm{~m}$, where no rocks are exposed in this area. The study area is located outside the range of faults and cracks [36].

\subsection{Restriction Sites}

Buffer zones are created around important sites or specific geographic features in each criterion within the GIS environment. These sites comprise areas which do not allow for a landfill site to be situated within them due to potential risks to the environment, human health, and excessive cost, as well as satisfying the governmental regulation requirements $[7,45]$. The buffer zones were created at a distance from each feature for the selected criteria based on literature review, as shown in Table 1.

Table 1. Description of values of buffer zones for criteria.

\begin{tabular}{cccc}
\hline No. & Criteria & Buffer Zone & Researchers' Suggested Buffers \\
\hline 1 & Rivers & $1 \mathrm{~km}$ & $1 \mathrm{~km}[33,34]$. \\
2 & Roads & $0.5 \mathrm{~km}$ & $0.5 \mathrm{~km}[14,43]$. \\
3 & Railways & $0.5 \mathrm{~km}$ & $0.5 \mathrm{~km}[15,46]$. \\
4 & Urban centers & $5 \mathrm{~km}$ & $5 \mathrm{~km}[41,47]$. \\
5 & Villages & $1 \mathrm{~km}$ & $1 \mathrm{~km} \mathrm{[14,42].}$ \\
6 & Archaeological sites & $1 \mathrm{~km}$ & $1 \mathrm{~km} \mathrm{[45,48].}$ \\
7 & Gas pipelines & $300 \mathrm{~m}$ & $250 \mathrm{~m}[14]$. \\
8 & Oil pipelines & $75 \mathrm{~m}$ & $250 \mathrm{~m}[28]$. \\
9 & Power lines & $30 \mathrm{~m}$ & $30 \mathrm{~m} \mathrm{[34,43].}$ \\
\hline
\end{tabular}

\subsection{Layers Maps of Criteria}

There are many sources used to prepare the required map layers within GIS for the present study. The first was digital maps (shapefile). The individual shapefile maps for topography, slope, river, road, urban centers, villages, gas pipelines, oil pipelines, power lines and railways were prepared accordingly using the internal reports of the Iraqi Ministry of Education [49].

The second source was converting the published maps into digital maps using the relevant information on each map. The shapefile of "soil types" was created from the map of exploratory soil of Iraq (scale 1:1,000,000) [37]. The shapefile of "agricultural land use" was obtained using the published map of the land capability map of Iraq (scale 1:1,000,000) [50], and the digital maps was checked by analyzing satellite images of the Babylon Governorate from 2011 [51]. The shapefile of "archaeological sites" was produced from the Archaeological Map of Iraq (2013) (scale 1:1,500,000) [52], to indicate the archeological and religious sites in this Qadhaa. The map of industrial areas (scale 1:400,000) [29] contributed to defining the industrial areas within Al-Hashimiyah Qadhaa.

For the third source, the readings from 170 wells for the groundwater depths in this Qadhaa were imported into GIS as features, then these data were converted to the shapefie using the button of "export data". To produce the shapefile map of groundwater depths the extension tool "kriging", 
within GIS, was used to generate an interpolation between the readings of groundwater depths. Finally, the digital map of "groundwater depth" was produce [53].

\subsection{Classification and Rating the Sub-Criteria}

Each criterion was classified into categories (sub-criteria), and to each category was given a suitability grading value. This classification was made based on the opinion of experts and literature reviews in this field, as well as various required and available data in the study area. In order to prepare each criterion and sub-criteria, a number of steps were performed using the spatial analysis tools in the dialog box within ArcGIS-Version 10.4 (e.g., Buffer, Clip, Extract, Overlay, Proximity, Convert, Reclassify and Map Algebra, etc.), (Table 2). The sub-layers of each layer were assigned from zero to ten.

Table 2. The weightings of criteria and the ratings of sub criteria of the input layer maps.

\begin{tabular}{|c|c|c|c|c|c|}
\hline No. & Criterion & Sub-Criteria Values & Sub-Criteria Ratings (R) & Criterion's Weight (AHP) & Area $\%$ \\
\hline \multirow{4}{*}{1} & \multirow{4}{*}{$\begin{array}{l}\text { Groundwater } \\
\text { depth }(\mathrm{m})\end{array}$} & $1.5-3$ & 1 & \multirow{4}{*}{0.2004} & 0.54 \\
\hline & & $3-4.5$ & 4 & & 37.05 \\
\hline & & $4.5-6.0$ & 6 & & 47.43 \\
\hline & & $>6.0$ & 10 & & 14.98 \\
\hline \multirow{2}{*}{2} & \multirow{2}{*}{ Rivers (km) } & $0-1$ & 0 & \multirow{2}{*}{0.1471} & 8.46 \\
\hline & & $>1$ & 10 & & 91.54 \\
\hline \multirow{3}{*}{3} & \multirow{3}{*}{$\begin{array}{l}\text { Elevation } \\
\text { (a.m.s.l.) }\end{array}$} & $11-20$ & 3 & \multirow{3}{*}{0.0709} & 0.36 \\
\hline & & $20-29$ & 7 & & 92.94 \\
\hline & & $>29$ & 10 & & 6.70 \\
\hline 4 & Slope (degree) & $0-5^{\circ}$ & 10 & 0.0463 & 100 \\
\hline \multirow{6}{*}{5} & \multirow{6}{*}{ Soils types } & Soil 8 (A) & 10 & \multirow{6}{*}{0.0709} & 0.9 \\
\hline & & Soil 5' (B) & 9 & & 56.29 \\
\hline & & Soil $5(\mathrm{C})$ & 8 & & 26.1 \\
\hline & & Soil 9 (D) & 7 & & 0.22 \\
\hline & & Soil 4 (E) & 6 & & 2.6 \\
\hline & & Soil $11(\mathrm{~F})$ & 3 & & 13.8 \\
\hline \multirow{10}{*}{6} & \multirow{10}{*}{ Land use } & Industrial Area & 0 & \multirow{10}{*}{0.0302} & 0.12 \\
\hline & & Urban Centers & 0 & & 0.93 \\
\hline & & Villages & 0 & & 3.15 \\
\hline & & Treatment plant & 0 & & 0.0002 \\
\hline & & Rivers & 0 & & 0.35 \\
\hline & & Archaeological & 0 & & 0.003 \\
\hline & & Agri. land & 0 & & 53.15 \\
\hline & & Orchards & 5 & & 7.752 \\
\hline & & Unused land & 10 & & 34.544 \\
\hline & & Agri. airport & 0 & & 0.0008 \\
\hline
\end{tabular}


Table 2. Cont.

\begin{tabular}{|c|c|c|c|c|c|}
\hline No. & Criterion & Sub-Criteria Values & Sub-Criteria Ratings (R) & Criterion's Weight (AHP) & Area $\%$ \\
\hline \multirow{3}{*}{7} & \multirow{3}{*}{$\begin{array}{l}\text { Agricultural } \\
\text { land use }\end{array}$} & Agricultural land & 0 & \multirow{3}{*}{0.0462} & 55.74 \\
\hline & & Orchards & 5 & & 8.32 \\
\hline & & Unused land & 10 & & 35.94 \\
\hline \multirow{5}{*}{8} & \multirow{5}{*}{ Roads (m) } & $0-500$ & 0 & \multirow{5}{*}{0.0463} & 15.2 \\
\hline & & $500-1000$ & 7 & & 12.76 \\
\hline & & 1000-2000 & 10 & & 19.18 \\
\hline & & $2000-3000$ & 5 & & 15.94 \\
\hline & & $>3000$ & 3 & & 36.92 \\
\hline \multirow{2}{*}{9} & \multirow{2}{*}{ Railways (m) } & $0-500$ & 0 & \multirow{2}{*}{0.0107} & 2.15 \\
\hline & & $>500$ & 10 & & 97.85 \\
\hline \multirow{4}{*}{10} & \multirow{4}{*}{$\begin{array}{l}\text { Urban centers } \\
\qquad(\mathrm{km})\end{array}$} & $0-5$ & 0 & \multirow{4}{*}{0.1471} & 24.23 \\
\hline & & $5-10$ & 10 & & 34.74 \\
\hline & & $10-15$ & 7 & & 26.01 \\
\hline & & $>15$ & 4 & & 15.02 \\
\hline \multirow{2}{*}{11} & \multirow{2}{*}{ Villages (m) } & $0-1$ & 0 & \multirow{2}{*}{0.1038} & 44.9 \\
\hline & & $>1$ & 10 & & 55.1 \\
\hline \multirow{3}{*}{12} & \multirow{3}{*}{$\begin{array}{l}\text { Archaeological } \\
\text { sites }(\mathrm{km})\end{array}$} & $0-1$ & 0 & \multirow{3}{*}{0.0302} & 6.95 \\
\hline & & $1-3$ & 5 & & 49.5 \\
\hline & & $>3$ & 10 & & 43.55 \\
\hline \multirow{2}{*}{13} & \multirow{2}{*}{$\begin{array}{l}\text { Gas pipelines } \\
\text { (m) }\end{array}$} & $\leq 300$ & 0 & \multirow{2}{*}{0.0146} & 2.89 \\
\hline & & $>300$ & 10 & & 97.71 \\
\hline \multirow{2}{*}{14} & \multirow{2}{*}{$\begin{array}{l}\text { Oil pipelines } \\
(\mathrm{m})\end{array}$} & $\leq 75$ & 0 & \multirow{2}{*}{0.0146} & 5.93 \\
\hline & & $>75$ & 10 & & 94.07 \\
\hline \multirow[b]{2}{*}{15} & \multirow[b]{2}{*}{ Power lines (m) } & $\leq 30$ & 0 & \multirow[b]{2}{*}{0.0207} & 3.05 \\
\hline & & $>30$ & 10 & & 96.95 \\
\hline
\end{tabular}

AHP: analytical hierarchy process; a.m.s.l.: above mean sea level.

The "groundwater depths" layer was divided into four categories. Depths between 1.5-3.0 m, $3.0-4.5 \mathrm{~m}, 4.5-6 \mathrm{~m}$ and more than $6.0 \mathrm{~m}$, according to groundwater depth readings, were given ratings values of 1, 4, 6, and 10 respectively (Figure 3a). For the "river" layer, a distance less than $1000 \mathrm{~m}$ from the boundaries of a river was scored zero to reduce the potential for river contamination from landfill. A distance of more than $1 \mathrm{~km}$ was scored as 10 (Figure $3 \mathrm{~b}$ ). The map of the "elevation" layer was divided into three categories according to the study area. Elevation areas between 11 and 20 above mean sea level (a.m.s.l.), and between 20-29 were given grading values of 3 and 7 respectively. Elevations areas of greater than 29. were given the higher rating value of 10 (Figure 3c). All lands in Al-Hashimiyah Qadhaa have a slope of less than $5^{\circ}$, and they were graded 10 (Figure 3d). Land slope is an important factor when selecting a landfill site. In this study, ten categories were incorporated into GIS to prepare the "land use" layer. These categories are urban centers, villages, industrial areas, archaeological sites, treatment plant, agricultural airport, rivers, agricultural land, orchards and unused land. The categories of "orchards" and "unused lands" were given scores of 5 and 10 respectively, while other categories were assigned a score of zero (Figure 3e). The layer of "soil types" in Al-Hashimiyah Qadhaa comprises six types of soils [40] (Figure 4a). These soil types are haur soils A (8), river basin soils, poorly drained phase $B\left(5^{\prime}\right)$, river basin soils, poorly drained phase $C(5)$, silted haur and marsh soils F (9), river levee soils D (4), and active dune land E (11). These types of soils (multiple input rasters) were merged in a single raster layer within GIS, and then they were giving scores of 10, 9, 8, 7, 6 and 5 respectively. 

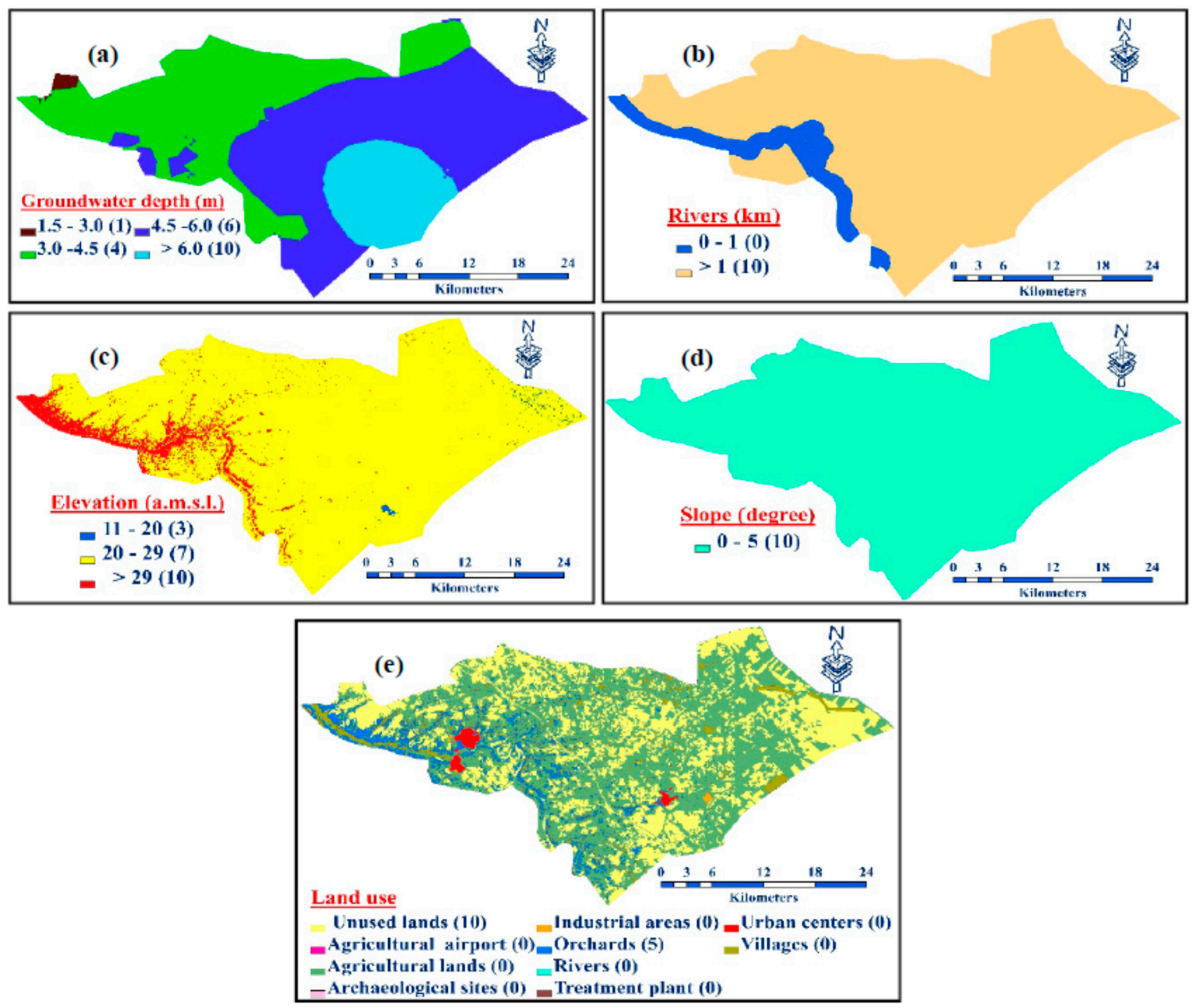

Figure 3. Maps of suitability indexes of (a) Ground water depth; (b) Rivers; (c) Elevation; (d) Slope; (e) Land use.

The layer of "agricultural land use" was divided into three categories. The categories of "agricultural land", "unused land" and "orchards" were given scores of zero, five, and ten respectively (Figure 4b). The layer map of "roads" included main roads and highways, and it has been divided into five buffer zone categories, buffer zones of less than $0.5 \mathrm{~km}$, buffer zones of $0.5-1 \mathrm{~km}$, buffer zones of 1-2 km, buffer zones of 2-3 km and greater than $3 \mathrm{~km}$ were given grades of zero, 7, 10, 5 and 3 respectively (Figure 4c). For the "railway" layer, buffer zones of less than $0.5 \mathrm{~km} \mathrm{~m}$ on both sides of the railway were scored zero. Buffer zones greater than $0.5 \mathrm{~km}$ were scored of 10 (Figure $4 \mathrm{~d}$ ). The layer map of "urban centers" was divided into four categories. Buffer zones of between of 5-10 km were given the highest score, which were 10. Buffer zones of 10-15 km, more than $15 \mathrm{~km}$ and less than $5 \mathrm{~km}$ were given a score of 7, 4 and zero respectively (Figure 4e). In the "villages" layer, buffer zones of less than $1 \mathrm{~km}$ were given a grading value of zero, while buffer zones greater than $1 \mathrm{~km}$ were scored 10 (Figure 4f) to protect human health and environment in these areas. For the "archaeological sites" layer, a buffer zone of less than $1 \mathrm{~km}$ was graded zero. Buffer zones of 1-3 km around these areas, and buffer zones more than $3 \mathrm{~km}$ were graded 5 and 10 respectively (Figure $4 \mathrm{~g}$ ). In the "power lines", "gas pipelines," and "oil pipelines" layers, buffer zones of less than $300 \mathrm{~m}$, that is $75 \mathrm{~m}$ and $30 \mathrm{~m}$ were given scores of zero. Buffer zones which were greater than these values were given a grading value of 10 (Figure $4 \mathrm{~h}, \mathrm{j}$ ). 

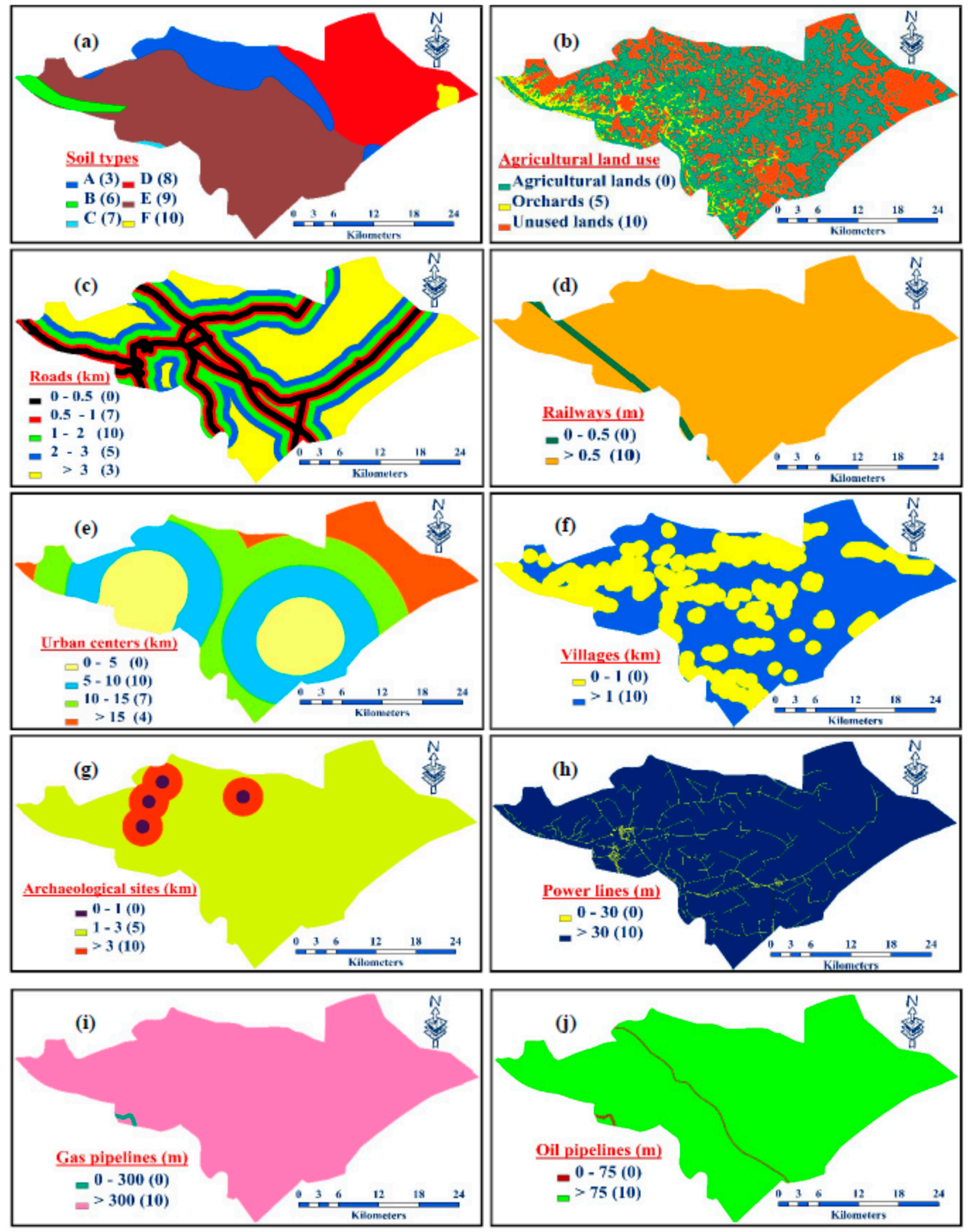

Figure 4. Maps of suitability indexes of (a) Soil types; (b) Agricultural land use; (c) Roads; (d) Railways;

(e) Urban centers; (f) Villages; (g) Archaeological sites; (h) Power lines; (i) Gas pipelines and

(j) Oil pipelines.

\subsection{Analytical Hierarchy Process (AHP) Method}

The AHP was applied to compute the significance of weightings for the selected criteria in the current study using a matrix of pair-wise comparisons [19]. The decision makers regarding weightings contributed through their experience and judgment in building the matrix of pair-wise comparisons 
through favoring the importance intensity of one activity over another using a numerical scale of 9 points. Each point equates to an expression of the relative importance of the two factors. e.g., "M has the same importance of $\mathrm{N}$ " or " $\mathrm{M}$ is more important than $\mathrm{N}$ ", etc. These studies use a scale with values ranging from 1 (equal importance) to 9 (absolute importance) [19,54].

The eigenvectors (Egi) were calculated for each row depending on multiplying the value for each criterion in each column in the same row in the matrix of the pair-wise comparison, and then taking the $\mathrm{n}^{\text {th }}$ root for numbers of elements in this row. Thus, this process was applied to each row. To calculate the priority vector (Pri) (relative weights) of criteria, an Egi for each criterion is normalized to 1 by dividing each weight by its sum. Checking the consistency between the weightings of criteria resulting from the matrix of pair-wise comparisons was done through estimating the Consistency Ratio (CR), by dividing the Consistency Index (CI) by the Random Index (RI), where RI is the mean deviation of randomness for matrices with different sizes for different values [19].

In this study, the value of Consistency Index $(C I=0.044)$ by the Random Index value $(R I=1.59)$ for $n=15$ (Table 3), where this table displays mean random index value RI for matrices with different sizes according to [15]. If the CR value is smaller than 0.1 , then the consistency is acceptable. Here, the $C R$ value was $0.027<0.1$. The judgments are completely consistent if $C R$ is equal to zero [55]. Perfect consistency is rare. Consequently, the AHP allows slight inconsistency in a matrix of pair-wise comparisons [3].

Table 3. Random inconsistency indices for different values of (n) [19].

\begin{tabular}{cccccccccccccccc}
\hline $\mathbf{n}$ & $\mathbf{1}$ & $\mathbf{2}$ & $\mathbf{3}$ & $\mathbf{4}$ & $\mathbf{5}$ & $\mathbf{6}$ & $\mathbf{7}$ & $\mathbf{8}$ & $\mathbf{9}$ & $\mathbf{1 0}$ & $\mathbf{1 1}$ & $\mathbf{1 2}$ & $\mathbf{1 3}$ & $\mathbf{1 4}$ & $\mathbf{1 5}$ \\
\hline $\mathrm{RI}$ & 0 & 0 & 0.58 & 0.9 & 1.12 & 1.24 & 1.32 & 1.41 & 1.45 & 1.49 & 1.51 & 1.48 & 1.56 & 1.57 & 1.59 \\
\hline
\end{tabular}

After preparing the weightings of the fifteen criteria from the matrix of pair-wise comparisons (Figure 5), the Suitability Index of Landfill Siting (SILS) for the final output map was calculated through the summation of the products of multiplying the weight of each criterion that was resulted from AHP method by the weight of each sub-criteria of each criterion based on previous studies and experts opinion (see Table 2). The special analysis tool "Map Algebra-Single Output Map Algebra" in GIS software was used for this purpose. The process of calculating (SILS) was as follows [14]:

$$
\begin{gathered}
\text { SILS }=(G W w \times G W s w)+(R V w \times R V s w)+(E w \times E s w)+(S L w \times S L s w)+ \\
(S o w \times S O s w)+(L U w \times L U s w)+(A G w \times A G s w)+(R o w \times R O s w)+ \\
(R W w \times R W s w)+(\mathrm{URw} \times \mathrm{URsw})+(\mathrm{VIw} \times \mathrm{VIsw})+(\mathrm{ARw} \times \mathrm{ARsw})+ \\
(\mathrm{GSw} \times \mathrm{GSsw})+(\mathrm{Ow} \times \mathrm{Osw})+(\mathrm{Pw} \times \mathrm{Psw})
\end{gathered}
$$

where: SILS: suitability index of landfill siting.

The terms "GWw, RVw, Ew, SLw, SOw, LUw, AGw, ROw, RWw, URw, VIw, ARw, GSw, Ow and $\mathrm{Pw}^{\prime \prime}$ refer to the criteria weightings of groundwater depth, rivers, elevation, slope, soil types, land use, Agricultural land use, roads, railway, urban centers, villages, archaeological sites, gas pipelines, oil pipelines and power lines respectively.

The terms "GWsw, RVsw, Esw, SLsw, SOsw, LUsw, AGsw, ROsw, RWsw, URsw, VIsw, ARsw, GSsw, Osw and Psw" are expressions for the weightings of sub-criteria for each of criterion which were mentioned above. 


\begin{tabular}{|c|c|c|c|c|c|c|c|c|c|c|c|c|c|c|c|c|}
\hline Criteria & 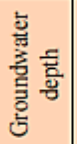 & 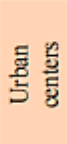 & $\begin{array}{l}3 \\
\text { 解 } \\
\text { 严 }\end{array}$ & $\frac{\mathscr{c}}{2}$ & 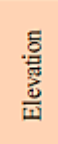 & $\frac{8}{\circ}$ & $\begin{array}{l}\text { चี } \\
\text { בै }\end{array}$ & 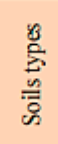 & 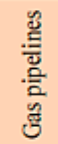 & $\frac{\frac{8}{0}}{\frac{.0}{0}}$ & 兽 & 骂 & 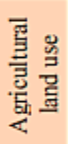 & 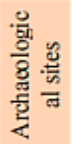 & 番 & 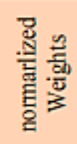 \\
\hline Groundwater depth & 1 & 2 & 3 & 2 & 4 & 5 & 5 & 4 & 8 & 8 & 7 & 6 & 5 & 6 & 9 & 0.2004 \\
\hline Urban centers & 0.50 & 1 & 2 & 1 & 3 & 4 & 4 & 3 & 7 & 7 & 6 & 5 & 4 & 5 & 8 & 0.1471 \\
\hline Villages & 0.33 & 0.50 & 1 & 0.5 & 2 & 3 & 3 & 2 & 6 & 6 & 5 & 4 & 3 & 4 & 7 & 0.1038 \\
\hline Slope & 0.20 & 0.25 & 0.33 & 0.25 & 050 & 1 & 1 & 0.5 & 4 & 4 & 3 & 2 & 1 & 2 & 5 & 0.0463 \\
\hline Roads & 0.20 & 0.25 & 0.33 & 0.25 & 0.50 & 1.00 & 1 & 0.5 & 4 & 4 & 3 & 2 & 1 & 2 & 5 & 0.0463 \\
\hline Soils types & 0.25 & 0.33 & 0.50 & 0.33 & 1.00 & 2.00 & 2.00 & 1 & 5 & 5 & 4 & 3 & 2 & 3 & 6 & 0.0709 \\
\hline Gas pipelines & 0.13 & 0.14 & 0.17 & 0.14 & 0.20 & 0.25 & 0.25 & 0.20 & 1 & 1 & 0.5 & 0.34 & 0.25 & 0.34 & 2 & 0.0146 \\
\hline Oil pipelines & 0.13 & 0.14 & 0.17 & 0.14 & 0.20 & 0.25 & 0.25 & 0.20 & 1.00 & 1 & 0.5 & 0.34 & 0.25 & 0.34 & 2 & 0.0146 \\
\hline Power lines & 0.14 & 0.17 & 0.20 & 0.17 & 0.25 & 0.33 & 0.33 & 0.25 & 2.00 & 2.00 & 1 & 0.5 & 0.34 & 0.5 & 3 & 0.0207 \\
\hline
\end{tabular}

Figure 5. Pair-wise comparisons' matrix for calculating the significance weights of criteria for landfill siting. Green color means the weights are equal

\section{Results and Discussion}

The final output map of the suitability index for selection of candidate sites for landfill in Al-Hashimiyah Qadhaa was produced based on determining the weightings of the sub-criteria of each criterion. Then, the weightings of the fifteen criteria were calculated using the AHP method. The suitability index map was classified based on four categories (Figure 6). These categories were "unsuitable", "moderately suitable," "suitable" and "most suitable." The area for each category and its proportion of the total study area was as follows: the "unsuitable" area was $40.97 \mathrm{~km}^{2}(8.89 \%)$, the "moderately suitable" area was $79.86 \mathrm{~km}^{2}(17.33 \%)$, the "suitable" area was $153.20 \mathrm{~km}^{2}(33.24 \%)$, and the "most suitable" area was $186.80 \mathrm{~km}^{2}(40.54 \%)$.

Thirteen categories of important areas with some of their buffer zones were excluded from the process of selection of sites for a landfill to simplify the process of selecting candidate sites for landfill (Figure 7). The features of these areas were entered into GIS as separate shapefiles, and then they were merged into a single shapefile using the button of merge in "Editor" option within the GIS software or using the special extension tool map algebra syntax (Merge "grid, ..., grid"). These categories were omitted from the final map for landfill in order to simplify identifying candidate sites for landfill in the study area. This means just $16.64 \%$ of the total present area is suitable for landfill siting. All excluded areas were given a score of zero.

Then, the excluded areas were extracted from the map of suitability index for landfill sites after merging in single shapefile (Figure 8).

In Al-Hashimiyah Qadhaa, the expected solid waste quantity in 2030 is 100,155 tonnes based on an estimated population in 2030 in this Qadhaa of 445,566 inhabitants using the following equation according to [10]:

$$
\text { Qs }(\text { for specific year })=\left(\left(P(2013)(1+0.0299)^{t}\right) \times\left(\operatorname{GRW}(2013)(1+0.01)^{t}\right) \times(365 / 1000)\right)
$$

where, Qs is quantity of waste produced each year (tonne), $\mathrm{P}_{0}$ is present population of the city for each year (starting from the year 2013), $r$ is an annual growth rate of $2.99 \%, t$ is number of years, GRW is present generation rate of solid waste (kg/capita/day) for the year 2013, RGI is rate of increment in waste generation per year equal to $0.01(\mathrm{~kg} /$ capita/day).

The expected cumulative quantity of solid waste for the years from 2020 to 2030 is 911,695 tonnes, according to calculations made by [10], as follows:

$$
\mathrm{Qs}_{(\mathrm{c})}=\mathrm{Qs}_{(\mathrm{ct})}+\mathrm{Qs}_{(\mathrm{ct}-1)}
$$


where, $\mathrm{Qs}_{(\mathrm{c})}$ : Cumulative quantity of solid waste for the specific year (tonne), $\mathrm{Qs}_{(\mathrm{ct})}$ : Quantity of solid waste for the specific year (tonne), $\mathrm{Qs}_{(\mathrm{ct}-1)}$ : Cumulative quantity of solid waste for the last year before specific year (tonne).

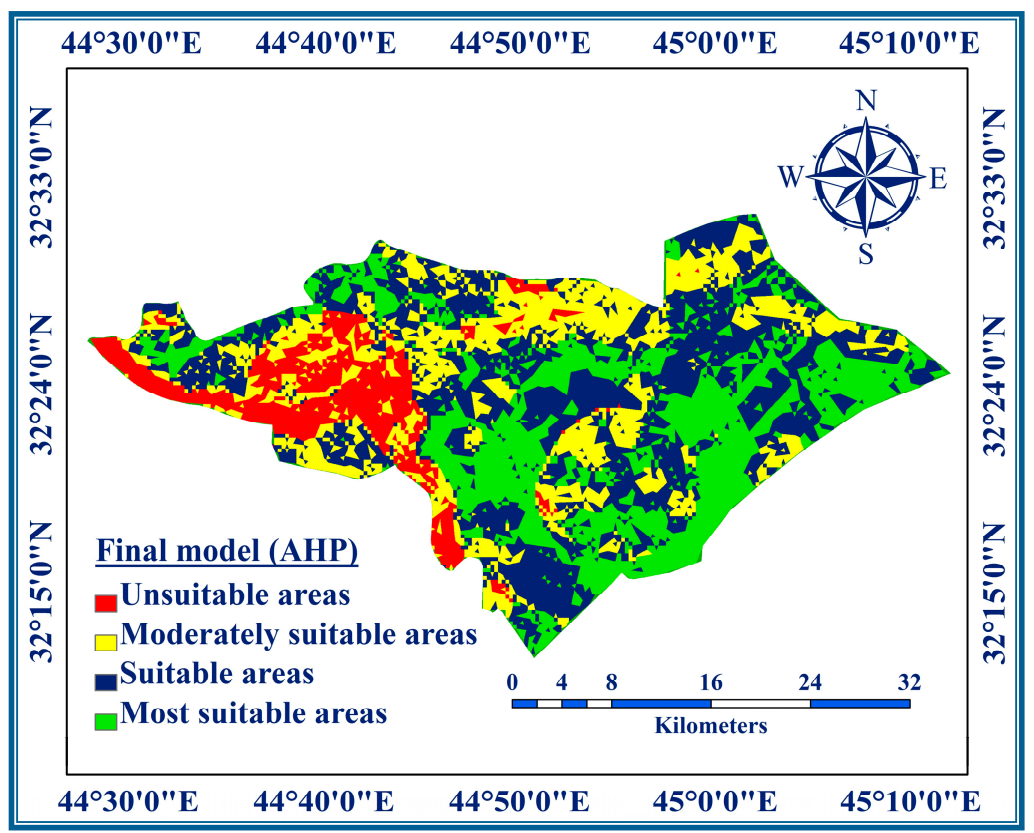

Figure 6. Map of suitability index for landfill sites in the study area.

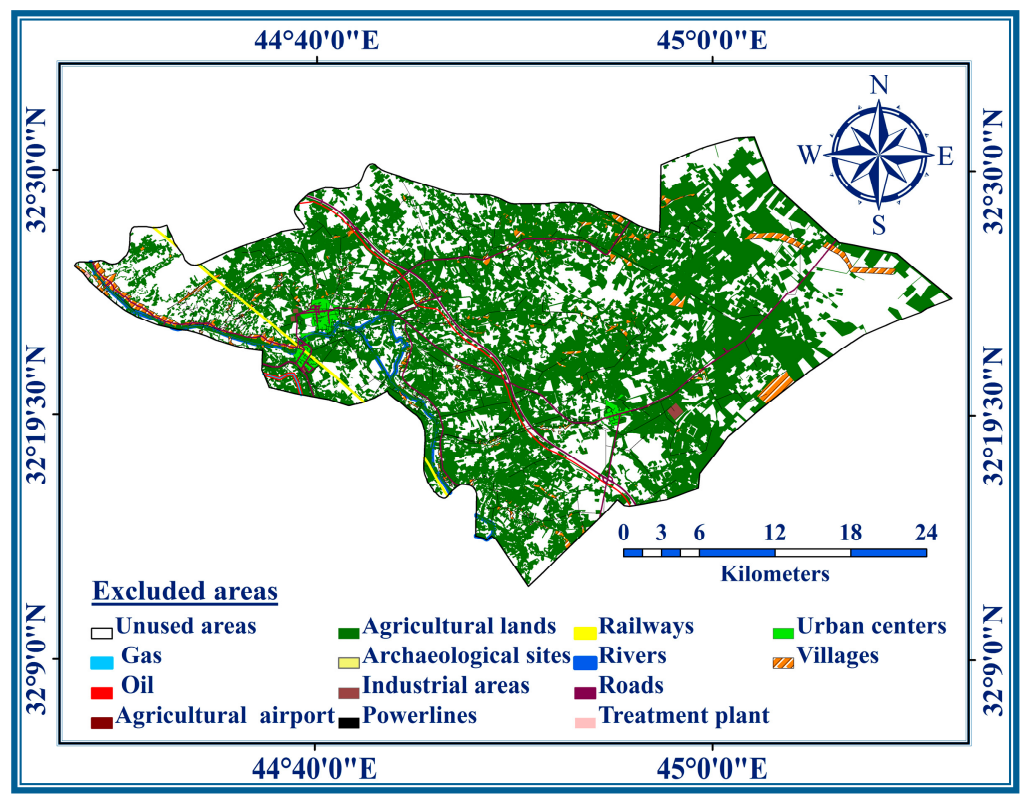

Figure 7. The map of excluded areas of the study area.

The expected volume of waste and the predictable volume of cumulative waste in 2030 are $222,567 \mathrm{~m}^{3}$ and 2,025,989 $\mathrm{m}^{3}$ respectively (Chabuk et al., 2015). These figures resulted from dividing the solid waste quantity over the density of waste in this Qadhaa $\left(450 \mathrm{~kg} / \mathrm{m}^{3}\right)$ according to Iraqi Ministry of Municipalities and Public Works (2015) [31]. An average groundwater depth of $2 \mathrm{~m}$ in the candidate sites for landfill in the study area was adopted because the groundwater depths in 
Al-Hashimiyah Qadhaa are shallow. Therefore, the required area for candidate sites to accommodate the cumulative quantity of solid waste generated from 2020 to 2030 is $1.013 \mathrm{~km}^{2}$.

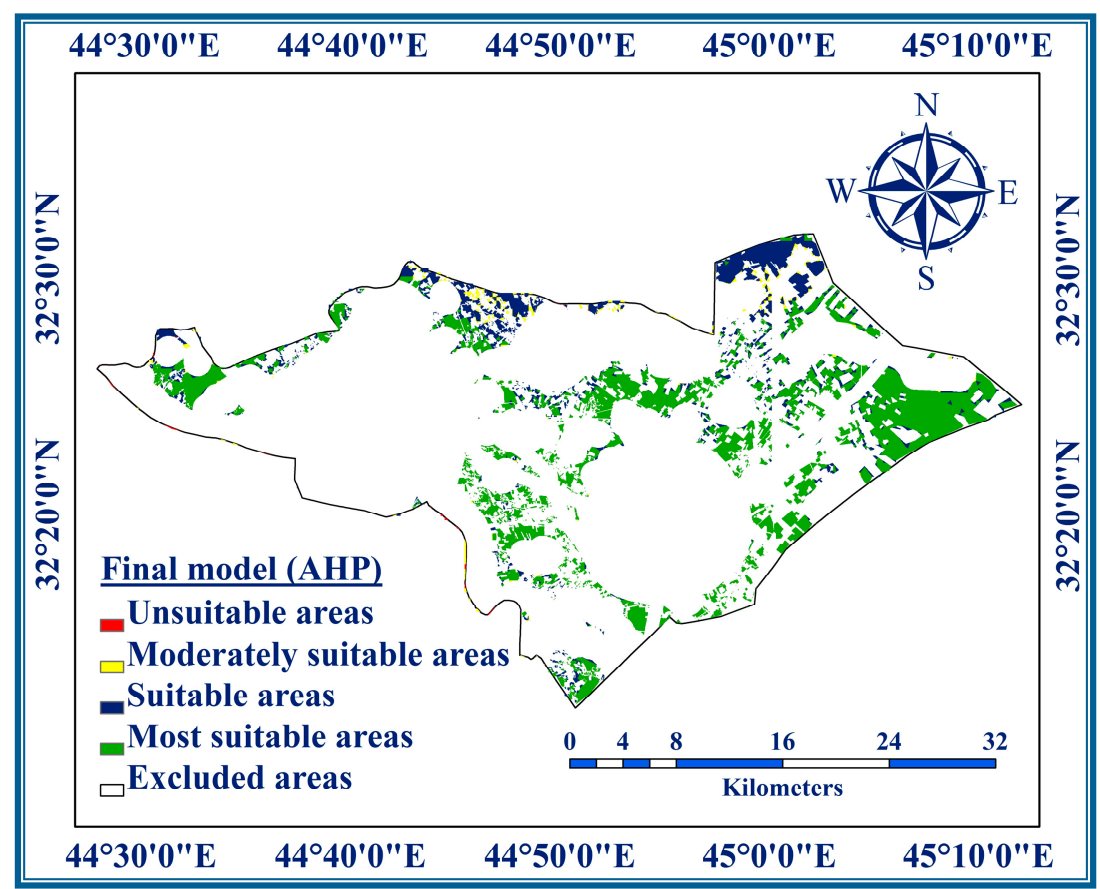

Figure 8. The final map after extracting excluded area with buffers.

Among the many sites situated within the category of the "most suitable" index, two candidate sites that fulfill the requirements in Al-Hashimiyah Qadhaa were selected for landfills. These sites were assigned numbers ( 1 and 2). The area of site No.1 is $1.374 \mathrm{Km}^{2}$ (latitude $32^{\circ} 24^{\prime} 51^{\prime \prime} \mathrm{N}$, and longitude $44^{\circ} 54^{\prime} 41^{\prime \prime} \mathrm{E}$ ), whereas the area of site No.2 is $1.288 \mathrm{~km}^{2}$ (latitude $32^{\circ} 15^{\prime} 54^{\prime \prime} \mathrm{N}$, and longitude $44^{\circ} 53^{\prime} 38^{\prime \prime} \mathrm{E}$ ) (Figure 9). These sites were checked on the satellite images (2011) of the Babylon Governorate to make sure that these sites were suitable for landfill.

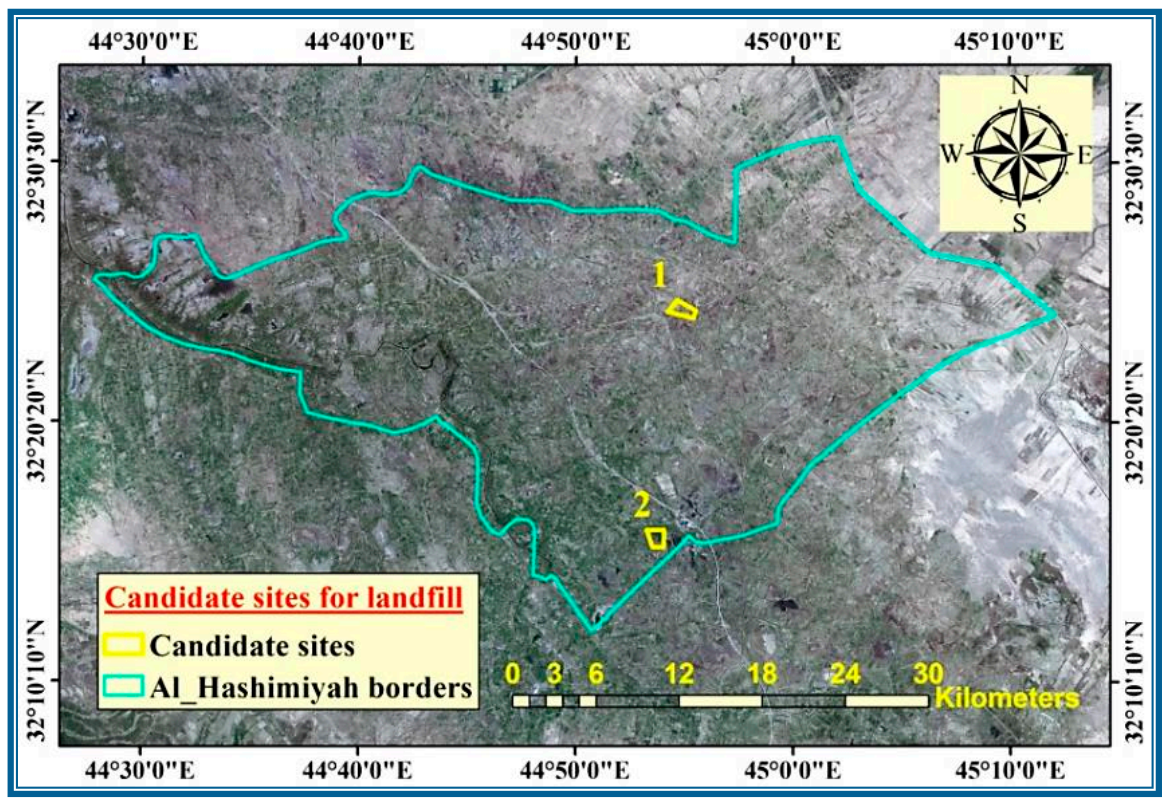

Figure 9. The candidate sites for landfill in Al-Hashimiyah Qadhaa. 


\section{Conclusions}

Recently, the increase of the generated solid waste quantity in Al-Hashimiyah Qadhaa and the needing to select a site suitable for landfill that fulfill the scientific and environmental criteria made the local authorities pay great consideration to this issue.

This study shows that the combination of GIS software and AHP using the multi-scientific and environmental criteria, which are followed in the developed countries, represents an effective and efficient methodology in the process of selecting suitable sites for landfill in Al-Hashimiyah Qadhaa. Fifteen layer maps were entered into the process of an overlaying analysis of potential areas with GIS to solve the problem of landfill siting in this Qadhaa, with GIS software having a high ability to manage a large volume of data from various sources. These layers were groundwater depth, rivers, elevation, slope, soil types, land use, agricultural land use, roads, railways, urban centers, villages, archaeological sites, gas pipelines, oil pipelines and power lines.

The criteria weightings were derived from the AHP method by constructing a matrix of sequences of pair-wise comparisons between criteria. The AHP method was used rather than the methods of multi criteria decision making because this method is based on theoretical foundation to check the consistency between the weights of criteria that are resulted from using AHP method.

In this study, to prepare the raster maps of selected criteria and produce the final map of landfill siting within the GIS software, many steps were performed using the special analysis tools. Each raster map for the selected criteria was divided into categories, and each category was given an appropriate weight. Then, using the special analysis tool in GIS "Map Algebra-Single Output Map Algebra", the final map of landfill siting was determined. For simplifying the process of selecting candidate sites for landfill, unsuitable areas for sites for landfill with some of their buffer zones were excluded.

For landfill siting in Al-Hashimiyah Qadhaa, two candidate locations were selected. In order to ensure that these sites were appropriate for landfill, the 2011 satellite image of the Babylon Governorate was used. The area of site No.1 was $1.374 \mathrm{Km}^{2}$, whereas the area of site No.2 was $1.288 \mathrm{Km}^{2}$. Therefore, the selected sites are adequate to accommodate the quantity of solid waste from 2020-2030 in Al-Hashimiyah Qadhaa.

The future work is using other models of multi-criteria decision making with GIS to select a suitable site for landfill. Using comparison methods between the raster final maps which will result from various models of Multi-Criteria Decision Making (MCDM). Using open source GIS software and (MCDM) methods to select the candidate site for landfills. Selection a suitable design for the chosen sites to prevent the groundwater pollution by leachate from these sites because the groundwater depth in Al-Hashimiyah Qadhaa is shallow.

Acknowledgments: University of Babylon, Iraq provided the first author a scholarship to do his PhD degree at Lulea University of Technology (LTU). LTU provided all the labs, computer facilities and software for the authors.

Author Contributions: Ali Chabuk and Nadhir Al-Ansari conceived and designed the experiments, Ali Chabuk, Nadhir Al-Ansari, Hussein M. Hussein, Roland Pusch and Jan Laue performed the experiments, Sven Knutsson, Roland Pusch and Jan Laue contributed reagents/materials/analysis tools, Ali Chabuk and Nadhir Al-Ansari wrote the paper.

Conflicts of Interest: The authors declare no conflict of interest.

\section{References}

1. Guerrero, L.A.; Maas, G.; Hogland, W. Solid waste management challenges for cities in developing countries. Waste Manag. 2013, 33, 220-232. [CrossRef] [PubMed]

2. Minghua, Z.; Xiumin, F.; Rovetta, A.; Qichang, H.; Vicentini, F.; Bingkai, L. Municipal solid waste management in Pudong New Area, China. Waste Manag. 2009, 29, 1227-1233. [CrossRef] [PubMed]

3. Moeinaddini, M.; Khorasani, N.; Danehkar, A.; Darvishsefat, A.A.; Zienalyan, M. Siting MSW landfill using weighted linear combination and analytical hierarchy process (AHP) methodology in GIS environment (case study: Karaj). Waste Manag. 2010, 30, 912-920. [CrossRef] [PubMed] 
4. Kontos, T.D.; Komilis, D.P.; Halvadakis, C.P. Siting MSW landfills on Lesvos Island with a GIS based methodology. Waste Manag. Res. 2003, 21, 262-277. [CrossRef] [PubMed]

5. Yesilnacar, M.I.; Cetin, H. An environmental geomorphologic approach to site selection for hazardous wastes. Environ. Geol. 2008, 55, 1659-1671. [CrossRef]

6. Kim, K.R.; Owens, G. Potential for enhanced phytoremediation of landfills using biosolids: A review. J. Environ. Manag. 2010, 91, 791-797. [CrossRef] [PubMed]

7. Siddiqui, M.Z.; Everett, J.W.; Vieux, B.E. Landfill siting using geographic information systems: A demonstration. J. Environ. Eng. 1996, 122, 515-523. [CrossRef]

8. Lin, H.; Kao, J. Enhanced spatial model for landfill siting analysis. J. Environ. Eng. 1999, 125, 845-951. [CrossRef]

9. Javaheri, H.; Nasrabadi, T.; Jafarian, M.H.; Rowshan, G.R.; Khoshnam, H. Site selection of municipal solid waste landfills using analytical hierarchy process method in a geographical information technology environment in Giroft, Iran. J. Environ. Health Sci. Eng. 2006, 3, 177-184.

10. Chabuk, A.; Al-Ansari, N.; Hussain, H.M.; Knutsson, S.; Pusch, R. Present status of solid waste management at Babylon Governorate, Iraq. Engineering 2015, 7, 408-423. [CrossRef]

11. Alnajjar, A.Y. Solid Waste Management Scenario in Iraq, Middle East, Solid Waste Management, EcoNENA. 2013. Available online: http://www.ecomena.org/tag/solid-waste-management-in-iraq (accessed on 17 January 2016).

12. El Alfy, Z.; Elhadary, R.; Elashry, A. Integrating GIS and MCDM to Deal with landfill site selection. Int. J. Eng. Technol. 2010, 10, 32-42.

13. Delgado, O.B.; Mendoza, M.; Granados, E.L.; Geneletti, D. Analysis of land suitability for the siting of inter-municipal landfills in the Cuitzeo Lake Basin, Mexico. Waste Manag. 2008, 28, 1137-1146. [CrossRef] [PubMed]

14. Şener, Ş.; Şener, E.; Karagüzel, R. Solid waste disposal site selection with GIS and AHP methodology: A case study in Senirkent-Uluborlu (Isparta) Basin, Turkey. Environ. Monit. Assess. 2011, 173, 533-554. [CrossRef] [PubMed]

15. Nas, B.; Cay, T.; Iscan, F.; Berktay, A. Selection of MSW landfill site for Konya, Turkey using GIS and multi-criteria evaluation. Environ. Monit. Assess. 2010, 160, 491-500. [CrossRef] [PubMed]

16. Aksaler, N.; Yerli, S.K.; Erdogan, M.A.; Kaba, K.; Ak, T.; Aslan, Z.; Bakis, V.; Demircan, O.; Evren, S.; Keskin, V.; et al. Astronomical site selection for Turkey using GIS techniques. Exp. Astron. 2015, 39, 547-566. [CrossRef]

17. Zhu, B.; Nie, Y.; Nan, R.; Peng, B. The FAST/SKA site selection in Guizhou province. Sources Scintill. 2001, 278, 213-218.

18. Duarte, L.; Teodoro, A.C.; Maia, D.; Barbosa, D. Radio astronomy demonstrator: Assessment of the appropriate sites through a GIS open source application. Int. J. Geol. Inf. 2016, 5, 209. [CrossRef]

19. Saaty, T.L. The Analytic Hierarchy Process; McGraw Hill: New York, NY, USA, 1980.

20. Saaty, T.L. Fundamentals of Decision Making and Priority Theory with AHP; RWS Publications: Pittsburg, PA, USA, 2000.

21. Rahman, A. GIS based DRASTIC model for assessing groundwater vulnerability in shallow aquifer in Aligarh, India. Appl. Geogr. 2008, 28, 32-53. [CrossRef]

22. Zhong-Wu, L.; Guang-Ming, Z.; Hua, Z.; Bin, Y.; Sheng, J. The integrated eco-environment assessment of the red soil hilly region based on GIS-a case study in Changsha City, China. Ecol. Model. 2007, 202, 540-546.

23. Vahidnia, M.H.; Alesheikh, A.A.; Alimohammadi, A. Hospital site selection using fuzzy AHP and its derivatives. J. Environ. Manag. 2009, 90, 3048-3056. [CrossRef] [PubMed]

24. Ramjeawon, T.; Beerachee, B. Site selection of sanitary landfills on the small island of Mauritius using the analytical hierarchy process multi-criteria method. Waste Manag. Res. 2008, 26, 439-447. [CrossRef] [PubMed]

25. Kara, C.; Doratli, N. Application of GIS/AHP in siting sanitary landfill: A case study in Northern Cyprus. Waste Manag. Res. 2012, 30, 966-980. [CrossRef] [PubMed]

26. Alavi, M.R.; Mokhtarani, N.; Mokhtarani, B. Municipal solid waste landfill site selection with geographic information systems and analytical hierarchy process: A case study in Mahshahr County, Iran. Waste Manag. Res. 2013, 31, 98-105. [CrossRef] [PubMed] 
27. Khan, D.; Samadder, S.R. Municipal solid waste management using Geographical Information System aided methods: A mini review. Waste Manag. Res. 2014, 32, 1049-1062. [CrossRef] [PubMed]

28. Uyan, M. MSW landfill site selection by combining AHP with GIS for Konya, Turkey. Environ. Earth Sci. 2014, 71, 1629-1639. [CrossRef]

29. Iraqi Ministry of Municipalities and Public Works. Structural Plan of Babylon Governorate, The Directorate General of Urban Planning 2009; Information Analysis Report (Revised), Stage 2; Iraqi Ministry of Municipalities and Public Works: Baghdad, Iraq, 2009; p. 223.

30. Iraqi Ministry of Planning. Records of Directorate of Census Babylon, Internal Reports; Iraqi Ministry of Planning: Baghdad, Iraqi, 2015.

31. Iraqi Ministry of Municipalities and Public Works. Records of Directorate of Babylon Municipalities; Iraqi Ministry of Municipalities and Public Works: Baghdad, Iraqi, 2015.

32. Şener, B. Landfill site selection by using geography information System. Master's Thesis, Middle East Technical University, Çankaya/Ankara, Turkey, August 2004.

33. Eskandari, M.; Homaee, M.; Mahmodi, S. An integrated multi criteria approach for landfill siting in a conflicting environmental, Economical and socio-cultural area. Waste Manag. 2012, 32, 1528-1538. [CrossRef] [PubMed]

34. Yildirim, V. Application of raster-based GIS techniques in the siting of landfills in Trabzon Province, Turkey: A case study. Waste Manag. Res. 2012, 30, 949-960. [CrossRef] [PubMed]

35. Demesouka, O.E.; Vavatsikos, A.P.; Anagnostopoulos, K.P. GIS-based multicriteria municipal solid waste landfill suitability analysis: A review of the methodologies performed and criteria implemented. Waste Manag. Res. 2014, 32, 270-296. [CrossRef] [PubMed]

36. Jassim, S.Z.; Goff, J.C. Geology of Iraq; Dolin, Prague and Moravain Museum: Brno, Czech Republic, 2006; p. 356.

37. Buringh, P. Soils and Soil Conditions in Iraq; The Ministry of Agriculture: Baghdad, Iraq, 1960; p. 337.

38. Zeiss, C.; Lefsrud, L. Analytical framework for waste-facility siting. J. Urban Plan. Dev. 1995, 121, 115-145. [CrossRef]

39. Baban, S.M.; Flannagan, J. Developing and implementing GIS assisted constraints criteria for planning landfill sites in the UK. Plan. Pract. Res. 1998, 13, 139-151. [CrossRef]

40. Tagaris, E.; Sotiropoulou, R.P.; Pilinis, C.; Halvadakis, C.P. A methodology to estimate odors around landfill sites: The use of methane as an odor index and its utility in landfill siting. J. Air Waste Manag. Assoc. 2003, 53, 629-634. [CrossRef] [PubMed]

41. Effat, H.A.; Hegaz, M.N. Mapping potential landfill sites for North Sinai cities using spatial multicriteria evaluation. Egypt. J. Remote Sens. Space Sci. 2012, 15, 125-133. [CrossRef]

42. Charnpratheep, K.; Zhou, Q.; Garner, B. Preliminary landfill site screening using fuzzy geographical information systems. Waste Manag. Res. 1997, 15, 197-215. [CrossRef]

43. Şener, B.; Suzen, L.M.; Doyuran, V. Landfill site selection by using geographic information systems. Environ. Geol. 2006, 49, 376-388. [CrossRef]

44. Chabuk, A.; Al-Ansari, N.; Hussain, H.M.; Knutsson, S.; Pusch, R. GIS-based assessment of combined AHP and SAW methods for selecting suitable sites for landfill in Al-Musayiab Qadhaa, Babylon, Iraq. Environ. Earth Sci. 2017, 76, 209-220. [CrossRef]

45. Ersoy, H.; Bulut, F. Spatial and multi-criteria decision analysis-based methodology for landfill site selection in growing urban regions. Waste Manag. Res. 2009, 27, 489-500. [CrossRef] [PubMed]

46. Wang, G.; Qin, L.; Li, G.; Chen, L. Landfill site selection using spatial information technologies and AHP: A case study in Beijing, China. J. Environ. Manag. 2009, 90, 2414-2421. [CrossRef] [PubMed]

47. Isalou, A.; Zamani, V.; Shahmoradi, B.; Alizadeh, H. Landfill site selection using integrated fuzzy logic and analytic network process (F-ANP). Environ. Earth Sci. 2013, 68, 1745-1755. [CrossRef]

48. Gupta, R.; Kewalramani, M.A.; Ralegaonkar, R.V. Environmental impact analysis using fuzzy relation for landfill siting. J. Urban Plan. Dev. 2003, 129, 121-139. [CrossRef]

49. Iraqi Ministry of Education. Data of the Directorate General, Internal Reports; The Department of Scientific Affairs: Baghdad, Iraqi, 2015.

50. Iraqi Ministry of Water Resources. State Commission of Survey, Internal Reports; Iraqi Ministry of Water Resources: Baghdad, Iraqi, 1990. 
51. Iraqi Ministry of Municipalities and Public Works. Directorate of Sewage Babylon, Internal Reports; Iraqi Ministry of Municipalities and Public Works: Baghdad, Iraqi, 2011.

52. World Digital Library. The Archaeological Map of Iraq. 2013. Available online: http://www.wdl.org/en/item/ 212/ (accessed on 24 September 2015).

53. Iraqi Ministry of Water Resources. General Commission for Groundwater, Internal Reports; Iraqi Ministry of Water Resources: Baghdad, Iraqi, 2015.

54. Hussain, M.H. Assessment of Groundwater Vulnerability in an Alluvial Interfluve Using GIS. Ph.D. Thesis, Indian Institute of Technology Roorkee, Roorkee, Uttarakhand, India, September 2004.

55. Coyle, G. The Analytic Hierarchy Process (AHP), Practical Strategy 2004, Open Access Material. Available online: https:/ / training.fws.gov/courses/references/tutorials/geospatial/CSP7306/Readings / AHP-Technique.pdf (accessed on 20 January 2016).

(C) 2017 by the authors. Licensee MDPI, Basel, Switzerland. This article is an open access article distributed under the terms and conditions of the Creative Commons Attribution (CC BY) license (http:/ / creativecommons.org/licenses/by/4.0/). 